\title{
Evaluating the Normative and Structural Explanations of Democratic Peace Theory
}

\author{
Yunizar Adiputera \\ Program on Humanitarian Action, Universitas Gadjah Mada
}

\begin{abstract}
Originating from the work of Immanuel Kant, Democratic Peace Theory proposes that democracies rarely, if ever, fight war against other democracies. While inquiries to the existence of such phenomena through sophisticated statistical approach remain important, it is equally important to further develop the understanding in the causal explanations behind it. There are two dominant strands of explanations for Democratic Peace, one locates the causes on the structure of democratic government, and the other locates them on the prevailing norms/cultures within a democratic society. The structural explanations claim that it is the institutions within democratic governments, such as the presence of regular election, checks and balances (from parliament), and transparency that hinder their leaders to initiate wars against other democracies. The norm/cultural explanations argue that democracies develop liberal ideology, norms of bounded competition, and reciprocity, which guide them in conducting peaceful foreign relations with other democracies. Despite the compelling logics brought by these two types of explanations, there remains a gap between their theoretical assumptions and practical realities of inter-state relations. Furthermore, some of these explanations need to be further specified in order to allow for more operational investigations to them.
\end{abstract}

Keywords: democratic peace, causal explanations, norms, institutions.

\begin{abstract}
Abstrak
Berawal dari hasil karya Immanuel Kant, Teori Democratic Peace mengajukan klaim bahwa negara-negara demokratis jarang, dan bahkan tidak pernah, berperang dengan negara demokratis lainnya. Meskipun penyelidikan melalui pendekatan statistik tentang ada tidaknya fenomena ini masih penting, tetap sama penting untuk mengembangkan lebih jauh pemahaman mengenai penjelasan kausal dari Democratic Peace. Ada dua arus penjelasan dominan untuk Democratic Peace, yang satu meletakkannya pada struktur dari pemerintahan demokratis, dan yang satu lagi meletakkannya pada budaya dan norma yang dianut oleh masyarakat demokrasi. Penjelasan struktural mengklaim institusi-institusi yang ada dalam pemerintahan demokrasilah, seperti pemilu yang rutin, checks and balances (dari parlemen), dan transparansi, yang menghambat pemimpin demokrasi untuk berperang melawan negara demokrasi lainnya. Penjelasan norma dan budaya mengatakan negara-negara demokrasi mengembangkan ideologi liberal, norma kompetisi terbatas, dan norma timbal balik, yang kemudian membimbing mereka untuk menjalankan hubungan luar negeri yang damai dengan negara demokrasi lainnya. Meskipun kedua jenis penjelasan memiliki logika yang kuat, terdapat jarak antara asumsi teoretis yang mereka buat dan realita praktis hubungan antarnegara. Selain itu, beberapa dari penjelasan-penjelasan tersebut perlu untuk lebih dibuat rinci agar dapat dilakukan penyelidikan operasional terhadapnya.
\end{abstract}

Kata kunci: Democratic peace, penjelasan kausal, norma, institusi. 


\section{Introduction}

Democratic Peace theory finds its root from the work of Immanuel Kant entitled Perpetual Peace. Essentially, democratic peace makes a claim on conditions for the attainment of peace. The hypothesis is that democracies do not go to war against other democracies. The Democratic Peace research program is important because its hypothesis is often used by leaders of contemporary liberal democracies to raise a claim as being more civilized and peaceful and to make better partners for trade and diplomacy. This is reflected, for example, in Bill Clinton's state of the union address in 1994, in which he said that the best way to "build a durable peace is by supporting the advance of democracies elsewhere," since "democracies don't attack each other" (Clinton, 1994). The belief in democratic peace has also been taking form in real policy actions. Looking at the last decade alone, we could find many instances in which war was waged in order to, at least officially, install democratic regime in several countries, with Iraq and Afghanistan being the most notable ones. Democracy also becomes the main logic of contemporary peace-building efforts, shown by many cases like East Timor, Kosovo, El Salvador, Nicaragua, Namibia, Mozambique, and scores of other countries (see Paris, 2004).

Since Kant, democratic peace proposition had regained attention in the 1980 s through Michael Doyle's seminal twoparts work. In the following decades, voluminous works had been produced to make sense of Democratic Peace theory. Research on democratic peace must be differentiated between those that try to prove its existence and those that try to explain why it exists. This article will engage extensively with the works of many authors on democratic peace, particularly those that represent distinct, and often competing, explanations of democratic peace. A brief history of democratic peace idea will be presented in the first part of this article as to give context to the subsequent debates. The second part of this article will discuss and evaluate the existing explanations of democratic peace propositions.
Democratic Peace: A History of an Idea Immanuel Kant's Perpetual Peace lay down the foundation for peaceful relations among nations. Kant argued that the state of nature among human beings who live to one another is not of peace, but of war, which is not always about the outbreak of hostilities, but also the constant threat of such hostilities (Kant, 2006, pp. 72-73). Hence, the state of peace must be established and cannot come naturally.

Kant, however, did not specifically refer to democracy as a source of perpetual peace. Instead, he drew three definitive articles, the acceptance of which would guarantee perpetual peace. The first definitive article holds that the civil constitution of the state must be republican. Three principles of republican state according to Kant is freedom of individual as men (human beings), dependence upon single common legislation as subjects, and equality as citizens (Kant, 2006, p. 74). Manifestation of these three principles is present in modern democratic governance, which rests upon representative government and separation of power (Doyle, 1983a, p. 226). Being republican state, according to Kant, prevents war because making decisions to declare war requires the consent of the citizens, whose inclination is naturally war-averse. Such inclination is caused by the thought of having to bear the calamities of war, like having to fight or having to pay the costs of war from their own resources (Kant, 2006, p. 75). On the contrary, a non-republican constitution led by tyrannical ruler does not have the same prudence of going to war because the ruler rarely suffers as much as those of his subjects.

The second definitive article of peace is the establishment of the so-called pacific union or a league of peace among republics. The pacific union allows an-ever expanding number of republics to maintain relations among themselves peacefully and prevents wars. Kant believed such idea is feasible especially if it were seen as a continuation of the first definitive article. If a number of people can make for themselves a republic, which is inclined to peace, then this "provides a focus point for other states, so that they might join this federative union and thereby secure the condition of peace among states in accordance with the idea of international right and 
gradually extend this union further and further through several such associations" (Kant, 2006, p. 80). The pacific union is neither a single treaty ending one war, nor a world government. The former is insufficient to make perpetual peace, while the latter is potentially tyrannical. According to Doyle, Kant may have projected pacific union as a kind of mutual non-aggression pact or a collective security agreement (Doyle, 1983a, p. 227).

The third definitive article is the existence of cosmopolitan law or the law of world citizenship. This is in conjunction with the pacific union of republics. The law, however, is limited to conditions of universal hospitality. Universal right of hospitality, according to Kant, is the right of foreigner not to be treated as enemy when he/she arrives in the land of another republic. This does not extend to give him/her the right of citizenship or permanent visitor, which requires special agreement. Hospitality mainly extends to include "the right of access and the obligation of maintaining the opportunity for citizens to exchange goods and ideas, without imposing the obligation to trade (a voluntary act in all cases under liberal constitutions)" (Doyle, 1983a, p. 227).

Kant's conception of liberal republics with pacific union and cosmopolitan law is compatible with contemporary understanding of democracy. The elements of liberal republics are connected with individual freedom, representative government, and separation of power, while pacific union and cosmopolitan law are mirrored in today's international treaties, free trade, and international commerce. This provides a basis for contemporary democratic peace authors to associate themselves with the work of Kant.

The idea that true and long-lasting peace could only be achieved through democratic governance was also reflected in the view of President Woodrow Wilson, who briefly had a grip just before the outbreak of World War II. In his famous Fourteen Points, Wilson put the idea of international peace through open covenant between nations observable by the public, which resembled pacific union as

${ }^{1}$ Small and Singer referred this as 'bourgeoisie democracy', which is characterized by the existence of imagined by Kant. In his war speech in front of Joint Session of Congress, Wilson reemphasized his thoughts that only democratic nations that could be trusted to maintain such pacific union:

\begin{abstract}
A steadfast concert for peace can never be maintained except by a partnership of democratic nations. No autocratic government could be trusted to keep faith within it or observe its covenants. It must be a league of honor, a partnership of opinion. Intrigue would eat its vitals away; the plottings of inner circles who could plan what they would and render account to no one would be a corruption seated at its very heart. Only free peonies can hold their purpose and their honor steady to a common end and prefer the interests of mankind to any narrow interest of their own (Wilson, 1917).
\end{abstract}

While the normative idea that democracies are more peaceful-either generally or toward each other-had not been unheard of since Kant, inquiries toward its empirical affirmation had not come out until Dean Babst published his statistical finding in 1972. Babst's work suggests that the existence of independent nations with elective governments greatly increases the chances for the maintenance of peace (Babst, 1972). Although Babst brought a very ambitious claim with his finding, his work received little attention and invisible at the time. Small and Singer departed from Babst's finding and conducted their own statistical research on the supposed peace among democracies. Their work reflected that of Babst's in its finding, that representative elected governments 1 are peaceful toward each other (Small \& Singer, 1976). Only after Small and Singer's work, which claimed robust statistical significance, did attentions toward the relations between democracy and peace begin to grow.

Michael Doyle's seminal two-part writing sparked a controversy in the academic world by introducing philosophical ground for the claim that there is the so-called "zone of peace" among democracies. Doyle drew his

organized opposition party and subordination of executive to the legislative. 
work mainly from Immanuel Kant and developed it further by elaborating the most notable legacies of liberalism: the pacification of foreign relations among liberal states and international imprudence. Pacification of relations among liberal states comes, among others, because the "guarantee of respect" resulting from state system, which separates one from another. This naturally brings closer liberal states, who shares similar moral foundations of freedom and progress (Doyle, 1983a, p. 230). At the same time, liberalism also brings the legacy of imprudence when it comes to dealing with non-liberal states. Doyle argued that imprudence comes as a consequence of liberalism itself, which becomes the intellectual guide in liberal states' foreign policy (Doyle, 1983b, pp. 324-325). Since liberalism posits respect toward individual autonomy as the basis of state legitimacy, it inevitably considers those who coerce their citizens as having lack of legitimacy. Liberalism assumes non-liberal states (those who coerce their citizens) are in constant aggression toward their citizens and, therefore, are assumed to be aggressive toward liberal states. These two claims-pacification and imprudence-signify the importance of Doyle's work and mark the beginning of burgeoning interests in the democratic peace research program in the academic community.

Since Doyle, there have been so many works dedicated to investigate democratic peace that it is impossible for the present article to account all of them. However, these works can be categorized through the methods and the approaches they use. The first wave of democratic peace researches uses quantitative method, since the most logical method of proving and disproving the existence of democratic peace is through statistical analysis. There are numerous authors who have engaged in this enterprise, and there have been extensive debates upon the statistical validity of democratic peace. The dominant issue surrounding democratic peace statistical investigation is on giving clear and commonly acceptable parameters of what counts as 'war' and 'democracy'.

While there are legitimate objections and debates on the definition of war, there has been a common use of the data from Correlates of War (CoW) as reference. The only contention usually revolves around the number of battle related fatalities and the number of personnel engaged (see, for example, Small \& Singer, 1976). A more contentious debate, however, is on the definition of democracy. Democratic peace authors usually define democracy within the confines of electoral process, norm of peaceful resolution of conflict, transparency and accountability, and parliamentary control toward executive branch. The disagreements often arise in determining the degree of these aspects. For example, how many free elections are required to take place before one country can be considered democratic? Or does there have to be a change of leadership during these elections?

It is noticeable that democratic peace authors mostly use datasets that are readily available to assess regime type; most popular among them are Polity IV and Freedom in the World. Many proponents of democratic peace have managed to use these datasets to prove the existence of democratic peace statistically. Rebuttals from opponents are mainly around the issue of rarity of democracies in general, geographical proximity among them, and reverse causality: peace causes democracy (James, Solberg, \& Wolfson, 1999; Mearsheimer, 1990). Nevertheless, the proponents keep developing their instruments to account all those factors, thus making democratic peace statistical claim more robust and consistent (Hayes, 2011, p. 5).

The second wave of democratic peace research combines the use of statistical analysis and the use of case study to investigate democratic peace proposition. In the second wave, the question starts to shift from asking 'whether it exists' to 'what causes it'. There are two prominent explanations of democratic peace coming out of the second wave research: norms and institutions. The former locates the cause of peace among democracies in the norms upheld by democratic polity, which are characterized by non-violence and cooperation. The latter emphasizes on structural hindrance in democracy that prevents leaders from easily declaring and engaging war with other democracies. There are many variants of normative and 
institutional explanations developed by different authors, some of them are competing with each other and some others are complementary.

The third wave of democratic peace researches digs further into normative and institutional explanations using mainly, but not limited to, constructivist approach. Other approaches in the third wave include evolutionary and psychological approaches. These approaches mainly employ case study to prove their claim.

When it comes to ask whether democratic peace exists, numerous statistical studies are ready to answer robustly, and adding the debate with more such studies give little value to democratic peace research. Answering the question of what causes democratic peace will contribute more to the subject, especially because there are plenty of variables-developed by many contemporary authors - $t$ verify. The next section shall engage with these variables extensively.

\section{The Causes of Democratic Peace}

It does not take long time after the rise of democratic peace as research subject for scholars to further the investigation to the causes behind the phenomenon. Starting in the 1990s, attempts have been made to rationalize the apparent state of peace between democratic countries. Two dominant streams of explanations are that of structure and norms. Within each, there are many variants of individual explanations, sometimes competing with each other. It is important to note that structural and normative explanations are deeply intertwined, making it difficult in certain situations to differentiate. This section shall take a look at these explanations and their logics.

\section{A. Structural Explanations}

The main tenet of structural explanations is that democracies develop a unique domestic political structure that characteristically limits the ability of their leaders to engage in wars, particularly with fellow democracies. There are three components in democratic structure that prevent war, namely regular elections, checks and balances, and transparency. Through regular elections, the public punishes leaders who are making foreign policy blunders, and since war opens up the possibility of such blunders, leaders will be deterred to opt for that policy. Checks and balances are done more directly through parliament, who has the power to turn down bad policies, including wars. At the very least, scrutiny from parliament will delay the escalation by the executive, allowing for other means of conflict resolution to take place. Lastly, government's transparent policy-making process allow potential foe to assess its resolve, and avoid misrepresentation and misunderstanding during crises.

\section{Regular Elections/Change of Leadership}

One of the most visible differences and oftcited indicator of democracy is the presence of fair and regular elections. Election is an instrument by which citizen can effectively influence the direction of the government, and hence, put control to the behavior of their leaders. Since the intention of rational politicians is to retain public office with decision-making power, and since such position is subject to public's accountability, politicians strive to avoid making foreign policy folly. The ability of the public to unseat unreliable politicians from office in case of bad policy, especially policies that drain public's resources like going to war, is one single reason why democratic leaders are more prudent in war decisions (see Reiter \& Tillman, 2002).

The biggest problem with the logic of regular elections as a hindrance of democratic wars is located in its presupposition that the public has the same set measurements of what "bad policy" is. This is often not the case. There are myriads of ways to judge whether a policy is good or bad, depending on what aspects are being valued more. Spending state's resources, for example, is not bad per se, depending on what are the gains that can be obtained and whether these gains are worth the spending.

With this logic, engaging in wars cannot be simply judged as a bad policy in itself, which will entail voters' disapproval. On the contrary, many wars are fought for exactly the reasons of maximizing gains. It is the result of the war that troubles voters. When a democratic leader goes to war and loses, then voters will "punish" this 
leader by unseating him/her. Obviously war is a risky game and leaders will fare better by avoiding it as much as they can. However, decisions to fight wars are not made in a vacuum. Specific circumstances may allow leaders to proceed with significant confidence that the war option will successfully achieve whatever their objectives may be. These circumstances may include superior military capacity, geographic advantages, international supports, element of surprise, etc. Putting these circumstances into account, it is not difficult to imagine how leaders may decide to go to war with the calculation that they will attain greater gains, thus securing their reelection.

\section{Checks and Balances through Separation of Powers}

In democratic governance, there is a visible division of powers among various political entities. Not only does the executive branch need support from legislature, but it must also be able to get approval from political bureaucracies and key interest groups. Due to the complexity of democratic process, which requires significant efforts and political capital, democratic leaders are disinclined to go to war, "except in cases wherein war seems a necessity or when the war aims are seen as justifying the mobilization costs" (Maoz \& Russett, 1993, p. 626). The lengthy process of democratic decision-making process provides a room for negotiation and compromise to take place. Non-democratic leaders face a very different environment. These leaders only need to secure support from key legitimizing groups in order to decide the use of force in foreign policy. With less people to convince, nondemocratic leaders can afford to stave off public opinion in matters dealing with other countries.

However, the fact that democratic countries practice separation of powers alone is not enough to hinder war decisions. The party system (two-party or multiparty) and the size of winning party/coalition affect the level of hindrance experienced by the executive in making war decision (Reiter \& Tillman, 2002). In cases where a democracy goes to war against non-democracy, it is mainly driven by the lack of structural constraints of the latter. The ability of non-democracy to wage war in shorter time puts the democratic state in a nochoice situation, in which emergency logic applies, thus enabling government to rally support rapidly.

The checks and balances from opposition group in parliament paint a much more compelling argument for democratic peace. However, there are some caveats. First, the size of the ruling party matters, because it is the one that will provide protection from opposing groups within parliament. Second, it is also important to assess the extent to which the checks and balances from the parliament will go. There are instances (different between democracies) where executives can take decisions through executive orders that, at least initially, can proceed without direct hindrance from parliament. Third, it is also important to take a look at what the opposition groups in parliament are opposing. Depending on the prevailing narrative surrounding the crisis, opposition may not hinder the war per $s e$, but rather oppose the manner in which the war is fought.

\section{Transparency}

In democratic countries, various political entities are not only allowed to oppose and directly constrain government's war decision, but they are also encouraged to express and show their opposition in public. This openness allowed outside observers, including potential rivals, to assess the degree of resolve and overall capacity of the democratic state to engage in wars. In a democratic state, "the government is not the lone voice of the state, it faces constraints on its ability to conceal or misrepresent its preferences for war and peace" (Schultz, 1999, p. 237). The role of opposition parties is of particular importance in this case since its support or resistance toward government's decision signifies political unity or political division, which, in turn, affects the state's performance in war efforts. The effect of transparency is that it decreases misunderstanding during crisis.

Another variant of explanation related with transparency is on signaling effect in democracy. Public in democratic state is more punishing to leaders who escalate a confrontation-by making provocative 
statement, troops movement, etc. - and then back down (Fearon, 1994, p. 586). Such inconsistency is a political disaster for every politician, but more so in a democratic environment. This makes democratic leaders more careful in making decisions that may escalate conflict and only do so in situations where they have strong confidence about going to war. Therefore, when a democratic leader escalates a conflict, outside observers may no longer question the leader's resolve to go to war, since his/her hands are tied to the socalled "audience cost" (see Fearon, 1997). Such signal of resolve may decrease the possibility of war by decreasing the game of bluffs.

Despite the fact that democracies are more easily scrutinized for policies they are making or they are about to make, there remains a certain degree of secrecy that democracies can nurture in their policymaking. This is especially the case with issues surrounding national security policies. Furthermore, democratic leaders, despite their accountability to the public, have at their disposal a means to avoid public scrutiny, such as the launch of covert operation. Many countries, including democratic ones, commonly do covert operations. This is evident in the way the U.S. was involved in the removal of Mossadeq of Iran, Jacobo Arbenz of Guatemala, and most notably Salvador Allende of Chile (see Downes \& Lilley, 2010). Therefore, there are potential limits to the transparency argument of democratic peace.

\section{B. Normative Explanations}

According to the normative camp of democratic peace explanations, democracies are characterized by liberal ideology, which adheres to non-violent conflict resolution, compromise, and the rule of law. Besides liberal norm, democracies also develop norm of bounded competition, which ameliorate competition by setting boundaries; and also norm reciprocity, which makes state choose to cooperate until it is defected upon. These domestic norms become the basis that shape democracies' international behavior. The projection of these norms onto the international system, when met with similar projection by other democracies, will create a zone of shared norms, characterized by peaceful interactions. However, when such projection of norms is met with antagonistic nature of non-democratic norms, the possibility of conflict may increase. The proponents of normative explanation argue that non-democracies are inherently antagonistic because they are in constant aggression with their people, whose freedoms are strictly limited.

\section{Liberal Ideology}

One of the operative mechanisms of norms advocated by normative camp is liberal ideology. Liberal ideology centers on individual freedom that orients on selfpreservation and prosperity. One important indicator of the existence of liberal ideology is the existence of freedom of speech, which allows citizens to engage fairly in public debates for the purpose of pursuing their interests. Free speech implies the equality before the law, which serves as a guarantee for the freedom.

John Owen argues that it is liberalism that really drives democracies to act pacifically to other democracies, although he admits that liberalism may not be exclusively embedded to democracy, and that some democracies may not necessarily be liberal in their ideology (Owen, 1994). The logic of this argument is quite simple: liberal ideology held by the society aims ultimately toward individual selfpreservation, which will be disrupted should war occurs, thus making peace as a more preferable option. This aversion to war happens only toward democracies because they share the same goals of self-preservation and material wellbeing, while nondemocracies commit to illiberal goals that threaten the realization of liberal goals.

The liberal ideology explanation tends to be very vague, and has little operational value. This vagueness also runs the risk of being a self-serving argument: since being liberal is inherently peace-loving, going to war means not being liberal. It is very difficult, therefore, to really prove or disprove this argument. There needs a further elaboration on the relations between liberal values and the preference for peace. But more importantly, it is important to take a look at what other norms are prevailing within the society, and how these 
other norms interact and reconcile with liberal values.

\section{Bounded Competition}

Another aspect of democratic norms that is believed to have contributed to the presence of democratic peace is the norms of bounded competition. Democracy is an avenue in which the public, through political elites, engage in an open competition for the right to govern. The nature of open-competitive system of democracy allows for the clash between conflicting material interests and basic political values, which at some level may create a deeply divided society. The competition can be observed not only in elections, but also happens in day-to-day politics such as legislations, policy executions, citizens who organize and express their interests through various associative arrangements, etc.

Just as competition is a constant of democratic governance, so are the presence of rules, procedures, or guidelines for setting its boundaries (Dixon, 1994, p. 15). Democratic society, at least at the level of political elites, is bound by the rules limiting and restricting what otherwise will be a violent political competition. Political actors in democracy agree on the 'rules of the game' and abide by them. The losers in elections are expected to acknowledge the winners and accept their policy decisions, so long as the election is fairly conducted and the losers are in no way banned from future participation.

They key tenet of the rules in democracy is that political actors are not to resort to violence in their objectives. Indeed, political actors in democracy do not employ physically coercive or violent means as a normal mode of competition. This does not necessarily mean politically motivated violence is absent in democracies, nor does it imply that democratic actors always compete fairly, nobly, or even legally. Bounded competition puts nonviolence as the prevailing norms in democratic processes.

Nevertheless, the norm of bounded competition developed in domestic political process does not necessarily translate to international norm. While in domestic polity the norm of bounded competition is safeguarded by enforcing institution (the police and judiciary), in international system such norm relies only on the trust developed by states among each other. The trust is defined through the pattern of interactions between both states over some period of time. This sort of trust takes time to grow, even among democracies.

\section{Reciprocity}

Although reciprocity is a primary norm of interactions in systems of self-help ranging from primitive communities to the interstate system, it is a particularly prevalent feature of democratic states. A liberal political order inculcates norms of reciprocity in its citizenry because the political foundation of democracy is built through compromises and negotiations, which mainly involves tit-for-tat strategies (Braumoeller, 1997, p. 380). As noted by Russel Leng, democracies are more likely to employ tit-for-tat strategy in foreign policy, with cooperation being the default strategy (Leng, 1993, p. 28). Therefore, states observe the attitude and behavior of other states as reference in formulating their own attitude and behavior. Since democracies are capable of reflecting peoples' interests in foreign policy, and cooperative behavior benefits the peoples, they put cooperation as the default stance in relations with other states. Only if they are defected will they reciprocate with the same manner. This means democracies cooperate until defected upon.

When the norm of reciprocity is projected into the international stage, what happens is that democracies reciprocate other democracies' cooperative behavior, resulting in incremental democratic cooperation. Dealing with non-democracies, which hold neither cooperative nor reciprocal norms, democracies reciprocate their antagonistic behaviors. However, this reciprocation argument needs to take into account the dynamics of states' relations over the course of history. For example, if two states have been in rivalry for a while, such as India and Pakistan, and one party (Pakistan) has gone through changes from democracy to autocracy and the other way around for a while, how would reciprocal relations between both states look like? How far back reciprocity would be deemed justifiable? These complex scenarios need to be 
addressed by reciprocity argument for it to be given enough credence.

\section{Conclusion}

Democratic Peace proposition has been a matter of intense and expansive academic as well as policy debates for around three decades now. As an idea, DP is provocative not only because it is often seen as the closest thing to an empirical law in international relations, but also because it brings about a profound ideological implication. DP departs from Kant's idea of "Perpetual Peace", which highlights his conception of liberal republics with pacific union and cosmopolitan law as a source of peaceful relations among states. By the $2 \mathrm{O}^{\text {th }}$ century, academics had rejuvenated Kant's idea by looking at the pattern of relations between democracies, which is characterized as peaceful. While statistical studies remain dynamic, inquiries toward the causal explanations have also been vibrant.

There are two main camps of these explanations: the normative camp and the institutional camp. The normative camp looks at democratic culture as the source of peace between democratic countries. Democratic culture includes the cling to liberal idea, principle of bounded competition and reciprocity. On the other hand, the institutional camp centers its explanations on the presence of democratic structure that functions as barriers for the decision to go to war between democracies. This structure includes regular elections, separation of powers, and transparency.

It is shown in this article that both camps need to refine their arguments to address several developing and challenging scenarios. They also need to be more precise and specific, so that it is methodologically possible to evaluate their claims. Further research in this area is needed to close the gap between theoretical and practical developments of inter-state relations.

$$
\text { *** }
$$

\section{Bibliography}

\section{Books and Articles}

Babst, D. (1972) A Force for Peace. Industrial Research, 14, 55-58.
Braumoeller, B. F. (1997) Deadly doves: Liberal nationalism and the democratic peace in the Soviet successor states. International Studies Quarterly, 41(3), 375-402.

Dixon, W. J. (1994) Democracy and the Peaceful Settlement of International Conflict. The American Political Science Review, 88(1), 14-32. doi:10.2307/2944879

Downes, A. B., \& Lilley, M. L. (2010) Overt Peace, Covert War?: Covert Intervention and the Democratic Peace. Security Studies, 19(2), 266306.

Doyle, M. W. (1983a) Kant, Liberal Legacies, and Foreign Affairs. Philosophy \& Public Affairs, 12(3), 205-235. . (1983b) Kant, Liberal Legacies, and

Foreign Affairs, Part 2. Philosophy \& Public

Affairs, 12(4), 323-353.

Fearon, J. D. (1994) Domestic political audiences and the escalation of international disputes. American Political Science Review, 577-592.

(1997) Signaling Foreign Policy Interests Tying Hands versus Sinking Costs. Journal of Conflict Resolution, 41(1), 68-90.

Hayes, J. (2011) Review Article: the Democratic Peace and the new Evolution of an old Idea. European Journal of International Relations. doi:10.1177/1354066111405859

James, P., Solberg, E., \& Wolfson, M. (1999) An identified systemic model of the democracy-peace nexus. Defence and Peace Economics, 1O(1), 1-37.

Leng, R. J. (1993) Reciprocating influence strategies in interstate crisis bargaining. Journal of Conflict Resolution, 37(1), 3-41.

Maoz, Z., \& Russett, B. (1993) Normative and structural causes of democratic peace, 1946-1986. American Political Science Review, 624-638.

Mearsheimer, J. J. (1990) Back to the future: instability in Europe after the Cold War. International Security, 15(1), 556.

Owen, J. M. (1994) How Liberalism Produces Democratic Peace. International 
Security, $\quad$ 19(2), $\quad$ 87-125.

doi:10.2307/2539197

Paris, R. (2004) The Origins of Peacebuilding. In At War's End: Building Peace After Civil Conflict. Cambridge University Press.

Reiter, D., \& Tillman, E. R. (2002) Public, legislative, and executive constraints on the democratic initiation of conflict. Journal of Politics, 64(3), 810-826.

Schultz, K. A. (1999) Do democratic institutions constrain or inform? Contrasting two institutional perspectives on democracy and war. International Organization, 53(2), 233-266.

Small, M., \& Singer, J. D. (1976) The warproneness of democratic regimes, 1816-1965. Jerusalem Journal of International Relations, 1(4), 50-69.

\section{Electronic Media}

Clinton, B. (1994, January 25) State of the Union Address. Washington Post. Retrieved from http://www.washingtonpost.com/wpsrv/politics/special/states/docs/sou 9 4.htm

Kant, I. (2006) Toward perpetual peace and other writings on politics, peace, and history. Yale University Press. Retrieved from http://books.google.com/books?hl=e $\mathrm{n} \& \mathrm{r}=\& \mathrm{id}=\mathrm{ERFJVLqqROIC} \& \mathrm{i}=\mathrm{fnd} \&$ $\mathrm{pg}=\mathrm{PR} 7 \& \mathrm{dq}=$ toward + perpetual + peac e\&ots=hmgCMH7Tvt\&sig=4IUZO7i8khiYJfcwVdS1BKZeYI

Wilson, W. (1917, April 2) Address to a Joint Session of Congress Requesting a Declaration of War Against Germany. The American Presidency Project. Retrieved March 18, 2013, from http://www.presidency.ucsb.edu/ws/ ?pid $=65366$ 